\title{
A Treatise on Socioeconomic Roles of Zakah
}

\author{
Shehu U.R. Aliyu*
}

Received: 16.09 .2018

Accepted: 20.03.2019

DOI: $10.25272 /$ ijisef.460304

Type: Research Article

\begin{abstract}
A major preoccupation of policymakers is the design and implementation of public policy for efficient resource mobilization, allocation, stabilization of the economy and redistribution of wealth to guarantee minimum standard of living for all. Capitalism and socialism at the extremes are characterized by the supremacy of self-interest and total state control, respectively. Exacerbated by the prevalence of riba in the systems, unwanted economic outcomes; social and economic inequality, poverty, unemployment, crimes, booms and recessions, thrive. The Islamic economic system which blends the material pursuit with spiritual upliftment tailors economic policies towards attainment of Maqasid al-Shari'ah. As a pillar of Islam and an omnibus instrument of economic stabilization, zakah serves as an automatic catalyst with backward and forward implications on resource mobilization, allocation, stabilization and redistribution of wealth. Using a heuristic approach, the paper conducts an in-depth assessment of the socioeconomic impact of zakah in an Islamic economy. Evidences from review of both classical and empirical literature unveil the positive impact of zakah on consumption, savings, investment, employment and higher productivity (Kahf 1980; Metwally 1983; Khan 1984; Ahmad, 1985; Kuran 2006; Azmi, 2009 and Norulazidah, Ali \& Myles, 2010. Additionally, zakah acts as an expansionary tool at lower income and discretionary tool at the higher income levels with a view to redistributing income, poverty and provision of public good for the benefit of the poor (Faridi, 1983). The paper argues that in view of the overwhelming empirical evidences in the literature, zakah is an effective tool for tackling socioeconomic problems of our modern times. It is recommended that the Muslim Ummah, especially in Muslim majority countries, should establish zakah institutions to improve socioeconomic condition of their people.
\end{abstract}

Keywords: Zakah, socioeconomic, resources allocation, stabilization, redistribution, poverty

Jel Codes: E62, I31, P24, Z12.

\footnotetext{
* Professor of Financial Economics at the Department of Economics and the Pioneer Director of the International Institute of Islamic Banking and Finance, Bayero University, Kano, Nigeria. ORCID: http://orcid.org/0000-0002-3712-4811 Email address: suarano.eco@buk.edu.ng
} 


\section{Introduction}

Economic stabilization within the context of Islamic economic system is embedded in the principles of the Shari'ah, otherwise the Islamic law. The tools or mechanisms and invariably the objectives of economic stabilization owe their origin to the broad Maqasid al-Shari'ah, that is, the objectives of Islamic law. Through economic stabilization, policymakers achieve managing the economic system free from extreme fluctuations in the aggregate level of prices, output, employment, disparities in income and opportunities ${ }^{1}$, as well as opening up of more frontiers for effective resource mobilization, and utilization. These culminate into attainment of socioeconomic justice for all and a balanced society. ${ }^{2}$ Accordingly, economic management must tally not only with the objective of attaining a stable and highly prosperous economy, but must ensure that the instruments are strictly within the confines of the Islamic laws. ${ }^{3}$ Contrary to the capitalist instruments of economic stabilization which are themselves cradles of destabilization in view of their strong association with riba, the Islamic instruments, and indeed the entire economic system have strong inbuilt mechanisms for stability and control. ${ }^{4}$ Thus, the pillars upon which the Islamic economic system of Islam is built are: prohibition of interest, and the implementation of Zakah (Yakoob, 2009).

Zakah is one of the foundations of Islamic economy based on social welfare and fair distribution of wealth to the poor (Ali and Hatta, 2014). It is both a pillar ${ }^{5}$ of Islam and an omnibus instrument of economic stabilization. It is a form of Islamic tax, right of the poor 6 ,

\footnotetext{
${ }^{1}$ What Allah has bestowed on His Messenger (and taken away) from the people of the township, belongs to Allah, to His Messenger and (his) kindred, the orphans, the needy, and the wayfarer in order that is may not (merely) make a circuit between the wealthy among you". Qur'an 59:7.

${ }^{2}$ In an Islamic economic system, the institution of zakah incorporates proper balance between the extremes of capitalism and communism (Mawdudi, 1975; and Hairunnizam and Radiah, 2010).

${ }^{3}$ According to Chapra (1979) "... that all instruments of direct and indirect controls, including wageprice controls and nationalization, to the extent considered necessary in the overall interest of the Muslim society. What instruments are to be used and to what extent, would be determined essentially by the circumstances, given the guiding principles of the Shari' ah.

${ }^{4}$ The Holy Qur'an states: Those who, when they spend, are not extravagant and not niggardly, but hold a just (balance) between those (extremes). (Q 25:67). The Qur'an further states: “Indeed We sent Our Messengers with Clear Signs and sent down with them the Book and the Balance that people may uphold justice..." Q57:25

${ }^{5}$ Narrated by Ibn Umar (RA): Allah's Apostle said: "Islam is based on (the following) five (principles): To testify that no one has the right to be worshipped but Allah and Muhammad (PBUH) is Allah's Apostle. To offer the (compulsory congregational) prayers dutifully and perfectly. To pay zakah (i.e. obligatory charity). To perform pilgrimage (i.e. pilgrimage to Mecca). To observe fast during the month of Ramadan." Regarding the injunction in the Holy Qur'an, Allah the Almighty says: "Alms is for the poor and the needy, and the officials (appointed) over them, and those whose hearts are made to incline (to truth) and the (ransoming of) captives and those in debts and in the way of Allah; and Allah is Knowing, Wise." Q9:60.

${ }^{6}$ The fourth Caliph Ali ibn Abi Talib (RA) says: "God has made it obligatory on the rich to provide the poor with what is adequate for them; if the poor are hungry or naked or troubled, it is because the rich have deprived them [of their right], and it will be proper for God to hold them responsible for this
} 
which is not only capable of ensuring economic stability, but is chiefly applied as a tool of wealth creation and redistribution, poverty alleviation and a social insecurity antidote. Therefore, an optimum allocation of resources in an Islamic economy requires a balance between the moral and economic imperatives of the society, given its income, and the state of technology. In this regard, Shafi (1979) outlines three objectives of wealth distribution in Islam; the freedom of individuals to pursue Allah's bounties in a normal way according to his ability, his aptitude, his own choice and liking, for Allah is the ultimate Giver (Q28:77 and 43:32); to enable everyone, the poor, the helpless, the needy, the paupers and the destitute to have a right to wealth and for the wealthy in the society to discharge their obligation and to a share their wealth (Q70:24-25 and 93:10); and to avoid concentration of wealth in the hands of few individuals (Q59:7). Furthermore, Faridi (1983) advances that the fiscal dynamics of an Islamic system, in view of absence of empirical studies, relies on relevant norms and values that are relevant to allocation, distribution and stabilization functions of the state and the model behavior of an Islamic economic system in the early period as the datum for theoretical projection of the future. These subsume not only the religious but the social as well as the economic aspects of human endeavors. Conceptually, socioeconomic pertains interaction between social and economic factors or indices such: occupational, educational income measures. ${ }^{7}$

Against this background, this paper employs a heuristic technique, a practical approach to problem solving, to assess the socioeconomic impact of zakah in an Islamic economy on the basis of injunctions from the Holy Quran and Sunnah, conceptual and empirical studies. It specifically analyzes the allocation, stabilization and distribution functions of zakah on individual livelihood and of the economy as a whole. The paper is organized as follows: section one deals with introduction while section two discusses the role of zakah in resource mobilization/allocation in an Islamic economy. Section three explores the thesis of zakah on stabilization of the Islamic economy. The significance of zakah as an antidote instrument for redistribution is presented in section four while section five offers concluding remarks and recommendations.

\section{Allocation Function of Zakah in an Islamic Economy}

Regardless of the type of economic system; capitalism, socialism or Islamic economic system, efficient allocation of scarce resources remains indispensable. The capitalist and socialist economic systems aside being purely materialistic in nature, push the four basic economic questions - what, how and for whom to produce, and who owns and controls the means or factors of production to the unmodulated forces of demand and supply and the machinery of the state, respectively. On the other hand, the Islamic economic system, in addition to the

deprivation and to punish them". In addition, Al-Qardawi argues that zakah is not just a form of worship but also that the receipt of the proceeds of zakah is a right of the poor.

${ }^{7}$ The indicators most commonly used as measures of socioeconomic status were derived from Duncan (1961). A Socioeconomic Index for all Occupations, pp. 109-138 in Occupations and Social Status, edited by Albert J. Reiss, Jr. New York: Free Press. 
seeking positive material advancement, entrenches the pursuit of material progression with spiritual upliftment as enunciated in the Shari'ah. ${ }^{8}$ The Shari' ah stipulates how the four basic questions should be addressed and regulates the economy neither by relegating it to the invisible hand nor by assuming complete ownership and control/disposition. ${ }^{9}$

Several studies established positive effect of zakah on the economy; Siddiqi, 1979; Rahman, 2003; Kuran; 2006 and Khan; 2007. The effect works through increase in aggregate demand leading to increase in capital stock and a rise in the economic growth trajectory of the economy. Therefore, evidence of both theoretical and empirical underpinnings on the role of zakah in mobilization and efficient allocation of scarce resource abound in the literature. Thus, as the pivot of Islamic fiscal policy, zakah promotes utilization of productive resources via empowerment of effective demand. Pioneering work in this regard include: Faridi (1983), Metwally (1983), Salama (1983) and Kahf (1983) in the compendium edited by Ziauddin.

Two strands of arguments in support of positive effect of zakah are: firstly, zakah constitutes a transfer of wealth from the rich to the poor, which invariably, have a higher marginal propensity to consume than the rich, hence a rise in the level of aggregate demand (Chowdhury, 1989; and Sadeq, 1990). Secondly, zakah payers will increase their savings ratio ${ }^{10}$ following intersectoral and intrasectoral allocation of resources utilization due to expansion in aggregate demand (Mannan, 1989). This is in spite of a fixed rate of zakah which causes depletion of idle wealth over time. Early scholars embedded these arguments within a static Keynesian model and came up with the conclusion that an increase in saving will ultimately be complemented by an increase in investment (Kahf 1980, Khan 1984). Similarly, Metwally (1983) and Azmi (2009) stress that that both the average propensity to consume (APC) and marginal propensity to consume (MPC) following zakah distribution would be higher in Islamic economy than in any other economy in view of its direct link to production and consumption. Furthermore, the demand for investment at a given expected rate of profit would equally be higher.

Though Norulazidah, Ali and Myles (2010) misconstrue zakah as purely voluntary payment in their model of overlapping generations, the authors, using the concepts of warm-glow (the reward the payer expects from making zakah payment and social custom (the religious obligation behind contributions to zakah) results show that zakah could raise the capital-labor

\footnotetext{
${ }^{8}$ The Qur' an says: "And seek in that which Allah has given thee, the home of the Hereafter; and neglect not thy share in this world..." (Q28:77). And when praying to the Almighty, a believer seeks the both the good in this world and the hereafter and enunciated in the Holy Qur' an as: "And there are some among them who say: Our Lord! grant us good in this world and good in the hereafter, and save us chastisement of the fire". Q2:201. ${ }_{9}^{9}$ According to Chapra (1979), the synthesis of the material and the spiritual aspects is missing in the welfare concepts of capitalism and socialism as they are both morally neutral... The fulfillment of the spiritual and material needs of individuals and the society would naturally necessitate the playing of a vital role by the State in the economic system of Islam.

${ }^{10}$ Chowdhury (1983) opines that zakah is likely to stimulate ex-ante savings of the zakah payers and capital formation because it irrevocably takes away a part of payer's net worth and hence may take precaution by increasing savings to avoid fall in future income level.
} 
ratio when it is motivated by the warm-glow. However, the social custom model could lead to a reduced capital-labor ratio as the rate of zakah increases. Earlier, Wahid (1985) applies the neoclassical model of labor supply in a micro context and concludes that zakah would increase individual labor supply if income effect of zakah is greater than substitution effect. Similarly, Awan (1980) analyses the effects of zakah on employment of labor and argues that zakah will leave employment unaffected.

Expeditiously, on the basis of different empirical studies: [Abdullah (1991) in Indonesia, Khan (1995) in Pakistan, Faridi (1995) in India, Ajeel (1995) in Kuwait, Abdul Wahab (1995) in Malaysia, Azharuddin (1988) in Bangladesh, Balogun (1999) and Dogarawa (2009) in Nigeria], it was projected that the institution of zakah serves as a unique philanthropic mechanism is capable of promoting participatory economic growth and development.

\section{Zakah and Macroeconomic Stabilization}

As an embodiment of fiscal policy, zakah acts both as an instrument of revenue generation and robust expenditure tool. It is capable of instilling macroeconomic stability in an Islamic economy. It regulates consumption among the rich without negating savings, promotes aggregate demand and invariably investment and paves way for non-inflationary growth in the gross domestic product (GDP). A number of pioneering works unveiled the positive impact of zakah on aggregate consumption based on a static Keynesian framework - see Kahf, (1983); Metwally, (1983); Khan, (1984); Ahmad, (1985); Darwish and Zain, (1985). Moreover, Iqbal (2002) uses the Keynesian model to prove that although Metwally overestimated the effect of zakah on average propensity to consume (APC) and marginal propensity to consume (MPC), the net effect on consumption is still positive. This is in spite of call for moderation in Islam which may somewhat contracts consumption. He further adds that aggregate consumption is a crucial component in the determination of level of income and prices and the stability of national income is linked to the stability of the MPC through the interaction of multiplier and accelerator coefficients. Similarly, Mannan (1989) found that zakah influences the composition of goods and services because an increase in the demand for necessities leads to an increase in their production.

Yusoff (2006) argues that zakah is an effective tool of economic stabilization working both as expansionary tool to provide income to those at lower level, and a discretionary tool to those at higher income level. His empirical findings were based on the application a Keynesian model in Malaysia. In this regard, a hadith of the Holy Prophet (PBUH) describes zakah as namaa which essentially means an expansionary tool. Inescapably, wealthy people who 'evade' paying zakah, for instance, by investing their cash earnings before the year ends manifestly hearken to the call of zakah by turning their cash into investments (Mannan, 1989). Meaning, when a wealth holder invests his hoarded wealth to evade a meagre 2.5 percent zakah rate, he is in actual fact rendering greater community service than what zakah would have achieved. More employment opportunities imply greater stimulus for growth and greater macroeconomic stability (Khan, 1983), Awad, 1985). 
On their part, Sarif and Kamri (2009) extol the positive effect of zakah on national savings and investment and allocation of resources, stabilization and economic growth. On the effect of zakah on national savings, Metwally (1986) posits that though zakah may reduce savings when viewed in absolute income sense but increase it in relative sense. Karwai (2012) emphasizes the role of zakah in reducing the risk of debt failure as debtors are specifically recognized as recipients. Expectedly, given the low rate of zakah compared to conventional taxes ${ }^{11}$ and coupled with the prohibition of riba ${ }^{12}$ and hoarding ${ }^{13}$ in the economy, both savings ${ }^{14}$ and investment will steadily flow.

Unenviably, inflation, uncertainty, business-cycles, booms and recessions are inextricably features of a capitalist economy. Routinely, economic management invariably involve measure aimed at containing inflationary and deflationary pressures. Eloquently, Rab (2006) describes devaluation of currency as a deliberate attempt to create inflation to siphon real value of goods and services. ${ }^{15}$ The author further argues that devaluation policy constitutes the worst fraud against humanity which breads concentration of wealth, segregation of labor, underemployment and poverty. Therefore, zakah collection and disbursement act as automatic force that stabilize the economy. However, Islamic economists like Khan (1983) opines zakah expenditure is inflationary in nature in view of higher MPC among its beneficiaries, especially the fuqara and masakin. Meaning, unplanned distribution of zakah during period of rising prices could be counterproductive to the poor because of imminent inflation. Therefore, some economists proposed budget surplus during period of rising prices and budget deficit during deflationary period thus the need for optimal zakah distribution mix among the different beneficiaries. ${ }^{16}$ Ultimately, zakah dampens both inflationary and deflationary pressures on the economy and prevents the economy from drifting into wanton recession.

\footnotetext{
${ }^{11}$ Tax rates in the Capitalist economies are obscenely high. For instance, tax rate in Scandinavian countries and other parts of Europe reaches as high as 48 percent. The former French Prime Minister, Francois Hollande, proposed a tax rate of $75 \%$ from an initial rate of $48 \%$ in December, 2012 , on income level above $€ 1 \mathrm{~m}$ (one million Euros). The proposed rate, though was turned down by the parliament, was estimated to affect between 7,000 and 30,000 households of the population of France.

${ }^{12}$ Among other series of injunctions on prohibition of riba (usury) in the Holy Qur' an, the Almighty Allah says: "O you who believe! Be careful of (your duty to) Allah and relinquish what remains (due) from usury, if you are believers." Q2:278 ${ }_{13}$ Concerning those who hide Allah's bounties, the Holy Qur' an says: "Those who are niggardly and bid people to be niggardly and hide what Allah has given them out of His grace; and We have prepared for the unbelievers a disgraceful chastisement." Q4:37

14 The Holy Qur'an speaks on how the Almighty Allah distributes His bounties unequally. “...We distribute among them their livelihood in the life of the world, and We have exalted some of them above others in degrees, that some of them may take others in subjection; and the mercy of your Lord is better than what they amass." Q43:32.

${ }^{15}$ According to Safi el Din in History and Rules of Currency Issuing in Islam, Adwaa el Shari'a, No. 12 (1982) pp. 209-237, deficit financing through printing of money is contrary to Islamic teaching since it is in effect a form of currency debasement which Islam frowns at as suggested by various pronouncements on the reduction of weight or quality of coins.

${ }^{16}$ In deciding the zakah mix, majority are of the opinion that the state may arrange the share of each group bearing in mind the need of the time, Imam Shafi'i, however, favors equal division among the
} 
El-Din (1986) supports the view that zakah can be paid in kind in the form of consumer and producer goods and the ratio between the two can be used a fiscal tool. ${ }^{17}$ He states that a reduction in the ratio produces dual effects: a fall in the consumer good will reduce the accelerator effect, and a rise in the producer goods will enable capital stock to be adjusted to its desired level as more zakah money is used in purchasing equities. On the other hand, an increase in the ratio during contractionary period will produce favorable expansionary effect since higher consumption oriented disbursement of zakah will help recovery to take place. It is instructive to note that the combined effects of these measures would curb excessive booms and recessions in the economy. The author further supports introduction of Zakah equity certificates and distribution of dividends the beneficiaries to promote production and dampen business-cycles.

\section{Zakah as Instrument of Distributive Justice and Social Security}

The inability of interest-based economic system to attain full employment and eradication of poverty has been pointed out in unmistakable terms by renowned economists like John Maynard Keynes, Samuelson and Domar. On the contrary, Islamic economists maintain that zakah performs major functions of modern public finance that deals with social security entitlements, social assistance, grants for childcare, food subsidy, education, health care, housing, and public transportation in a welfare state. zakah mitigates social inequalities incurred as result of exploitative economic behavior of man and covers the areas of social justice and social security (Shehatah, 1989; Qardawi, 1999; Yusoff, 2008; Mohsin, 2013). In particular, Muslim experts concur that zakah is the best "pro poor growth" model that would achieve maximum effect on poverty ${ }^{18}$, provided it is allocated on the basis of the poverty rate ${ }^{19}$ and the quality of economic policy (El-Din, 1986; Hairunnizam and Radiah, 2010; Hassan, 2007; Yusoff, 2008; Dogarawa, 2009; Ibrahim and Nirmala (2011); Fuadah et al., 2013 and Malik, 2016).

In spite of this, it is pertinent to emphasize that seeking for life sustenance is a religious duty on every abled individual in the Islamic state and that one should not unnecessarily constitute

eight groups. The Malikis and Hanafies do not accept time lag between collections and spending of zakah without any valid reason. However, a time lag of a few days is permissible.

${ }^{17}$ For instance, historians reported that when inflationary pressures appeared in the days of the Caliph Umar Ibn Khattab (RA) following receipt of kharaj from the conquered lands in cash, the Caliph astutely instructed his provincial governors to send the tax in kind, particularly grains and oil. He also resorted to borrowing against future Zakah revenue when he needed camels for the armies and did not possess the required funds.

${ }^{18}$ This is evident in view of the fact that six out of the eight heads of expenditure on whom zakah revenue can be spent on have correlation with poverty in one way or another.

${ }^{19}$ El-Din (1986) summarizes the views of the classical schools of thought as: according to the Hannafi School sets a limit of 200 dirhams while the Shafi'i recommends a life support by giving capital goods to eligible persons. The Maliki School allows giving a year's provision. Qardawi supports Maliki's view in case of zakah disbursement to children and disabled persons, and Shafi'i's opinion for disbursement to able-bodied and qualified persons. 
a burden on others. ${ }^{20}$ Accordingly, it is a moral responsibility of an individual to cater for his own needs through his own efforts. The role of the State through zakah and other social security instruments is therefore to fill the gap that could arise due to differences in natural or physical characteristics of individuals that could impair attainment of decent standard of living and in view of the fact that the Almighty, in His own wisdom, distributes His bounties unequally. ${ }^{21}$ Sadly (1990) emphasizes that when the Islamic mechanism of functional distribution of income through just factor pricing is implemented, distribution of income is expected to be more equal. When this is supported by the redistributive role of zakah as a compulsory transfer payment, income distribution will be more equal (Awad, 1989). Social justice, quest for sustainable security and equitable redistribution of income could be achieved through Zakah, waqf and interest-free loan systems (Ahmed, 2007; Cizakca, 2000; Raimi et al., 2013).

Thus, as a subset of public finance, distributive justice in Islam enjoins the State to guarantee a respectable standard of living to all individuals through proper job training, equal access to job opportunities, social security, financial assistance to the needy and the poor. Faridi (1983), for instance, identifies two approaches of redistributing real incomes through zakah revenues. These are through transfer payments (in cash or kind) or through direct provision (through public expenditure) of certain important socioeconomic infrastructure to the poor. However, a mix of both the approaches is a realistic policy goal.

Under the transfer payment approach, the Islamic government uses zakah as a negative tax where income is redistributed to the poor at a level enough to keep him above a defined poverty threshold. Some scholars however observe that this may affect work effort when the lump sum transfer discourages one from seeking for work. ${ }^{22}$ Alternatively, some scholars favor the exhaustive expenditure approach through provision public goods such as education and healthcare. Thus, Faridi (1983) emphasizes that an increase in the supply of education, Medicaid, Medicare facilities through zakah proceeds to the poor has a redistributional role as well as conferring direct financial benefit on the recipients and enhances future financial returns in terms of increased earnings. ${ }^{23}$ Scholars interpret spending on social infrastructure projects as synonymous to spending in the 'fi sabeelillah' (cause of Allah). Despite concerns by

\footnotetext{
${ }^{20}$ The Qur' an says: "And seek in that which Allah has given thee, the home of the Hereafter; and neglect not thy share in this world..." (Q28:77). In addition, Islam condemns begging and laziness and instead it stresses hard work and dedication. The Holy Prophet says: Beg not anything from people; the hand that giveth is better than the hand that receiveth. In another Hadith, that a man has not earned a better income than that which is from his own labor. Furthermore, the second caliph, Umar ibn Khattab (RA) epitomizes earning one's own livelihood saying: No one of you should stay away from seeking livelihood through hard work and say $O$ God! Give me sustenance', for the sky will not rain gold and silver.

${ }^{21}$ The Almighty Allah says: "Will they distribute the mercy of your Lord? We distribute among them their livelihood in the life of this world, and We exalted some of them above others in subjection; and the mercy of your Lord is better than what they amass." Al-Qur'an 43:32. See also 6:165

${ }^{22}$ Shehatah (1989) argues that zakah will not affect work effort especially when it is given to able-bodied persons.

${ }^{23}$ In addition, Sadeq (1990) argues that zakah can raise the standard of living of the poor through improved healthcare and skills acquisition programmes and ultimately contributes to economic growth.
} 
some scholars on free-rider problem, Imtiazi, Mandan, Niaz and Deria (1989) state that provided the problem can be minimized or when those not entitled to zakah can be made to pay, such infrastructure should be provided.

More broadly, the views of Allama Syed Rashid Riza and Sheikh Mohamoud Shaltout on what constitutes in the cause of Allah include public welfare expedients (goods) that may not only pertain to an individual and benefit of which does not accrue to an individual alone. Sheikh Hasanain Makhlouf, Mufti of Egypt, says it permissible to use zakah funds to fund Islamic welfare organizations (for their maintenance). Yousuf Qardawi's view of ' $f$ i sabeelillah' includes establishment of centers of learning for the Muslim youth, centers for propagating Islam and Islamic values in every nook and corner of the world, preparation of literature which may counteract the literature published for misguiding the Muslims, the publication of impressive books on Islam, the assistance to all those Muslims who have to bear all the atrocities at the hands of the enemies of Islam and the context with the latter on the ideological and cultural front.

Unleashing the capacity of zakah in achieving redistribution of wealth, Zarqa (1976) and Awad (1977) report zakah estimates for Syria and Sudan, respectively, indicate that the amount reached 3 to 4 percent of annual GNP. By way of extrapolating, Awad (2000) states that since public consumption in developing countries averages about 13 percent of the GNP, a single tax that draws 3 percent to 4 percent of annual GNP constitutes a significant transfer from the rich to the poor which few wealth taxes in the world can be that effective. Thus, Al-Mamun and Haque (2015) argue that the goals of distribution of Zakah therefore are; to decrease inequality, establish human rights, remove social injustice and empowerment of the poor people. The failure of the "Trickle Down" economic model in contemporary economics is very glaring as adjudged by poor economic conditions, especially of less developed countries. Evidence, for instance, shows that when the richest 20 percent of the society increase their income by 1 percentage point, the annual rate of growth shrinks by nearly 0.1 percent within five years (IMF, 2015).

Further, Hoque, Khan, and Mohammad (2015) investigate the cause of poverty in Muslim countries, the effectiveness of zakah management institutions, the mode of zakah distribution and the necessity for an entrepreneurial framework. They found that poverty is not due to lack of resources only, but in most cases due to lack of participation and entrepreneurship. Hence, introduction of entrepreneurship development programs through the institution of zakah could promote economic growth. Earlier, a study by Shirazi and Amin (2006) shows that 15 out of 37 Muslim economies (OIC member countries) require only a small amount of resources for poverty alleviation which no doubt could come through zakah.

Extending the frontiers of Islamic social security system, Muslim scholars opine that zakah could be disbursed to the non-Muslims who are generally poor provided that they are made to pay at least the equivalent of zakah in the form of some kind of welfare tax. Documented 
historical evidences in the early days of Islam allude to this view. ${ }^{24}$ This clearly operationalized the Islamic concept of universal brotherhood, thereby attracting non-Muslims to the fold of Islam. Besides, it is the duty of an Islamic State to ensure provision of minimum living standard for all its citizens including non-Muslims as well.

\section{Concluding Remarks and Recommendations}

The paper seeks to analyze the socioeconomic effects of zakah, an omnibus instrument of Islamic fiscal policy on the basis of injunctions from the Holy Quran and the Sunnah, conceptual and empirical studies. Using the heuristic approach, the paper analyzes the allocative, stabilization and distributional functions of zakah on individual livelihood and at the level of the economy as a whole.

Firstly, an important consideration in both conventional and Islamic macroeconomics is how resources are efficiently allocated. The paper found that zakah promotes consumption especially among people (needy and poor) with higher MPC, without impeding investments, raises overall productivity and improves wellbeing of the society. Secondly, as the economy grows and prosper, the challenge of maintaining economic stability emerges. The paper discovers within the context of Islamic economic broader principles: absence of riba, profit and loss sharing arrangement, zakah doubles as an effective economic stabilization instrument: an expansionary tool to provide income to those at the lower level, and a discretionary tool to those at higher income level. Furthermore, inflation, uncertainty, business-cycles, booms and recessions which inextricably are permanent features of capitalism are effectively brought under control through the automatic stabilizing effect of zakah on the economy. Thirdly, in line with the cardinal Islamic principles of justice, fairness and equity, zakah plays the role of modern public finance: provision of social security, fighting inequality in the distribution of wealth, alleviating poverty, provision of socioeconomic infrastructure, promotion of mutual harmony and social cohesion, in the society (Awan, 1980; and Mawdudi, 1988).

In conclusion, zakah in an Islamic economy is much more than a pillar of Islam or a tax on wealth. It was found that Zakah exerts great influence on socioeconomic wellbeing of the society, impacts positively on resource allocation, stimulates economic stabilization and capable of promoting distributive justice and social security. Its proper application through efficient system of collection and distribution is capable of solving the challenges of our modern times. Accordingly, this paper calls the establishment of more zakah institutions and reinvigoration of existing ones in Muslim countries, especially in Nigeria and sensitization of zakah payers to be alive to their religious obligation.

\footnotetext{
${ }^{24}$ Caliph Umar Ibn Khattab (RA) stressed that he is the supporter of him who has no supporter and as a mark of his sense of responsibility, he ordered a beggar's name, despite being a Jew, to be included those entitled to a stipends from the Islamic treasury.
} 


\section{References:}

Abdullah, Taufik (1991). Zakat collection and distribution in Indonesia, in The Islamic Voluntary Sector in Southeast Asia, Ed. Mohammed Ariff. Pasir Panjang, Singapore: Institute of Southeast Asian Studies.

Abdul-Wahab, Mohammed, et al., (1995). Malaysia: A Case Study of Zakat Management. In el-Asker and Sirajul Haq (eds.), Institutional Framework of Zakat: Dimensions and Implications, Jeddah, IRTI/IDB, pp. 297-378.

Ahmad, Ausaf (1985). Income Determination in an Islamic Economy, Jeddah, Scientific Publishing Centre, King Abdulaziz University, Jeddah, Saudi Arabia.

Ahmed, H. (2007), "Waqf-based microfinance: Realizing the social role of Islamic finance", presentation at International Seminar on Integrating Awqaf in the Islamic Financial Sector, Singapore, March 6-7.

Ajeel, Abdu Al Qader Dahl (1995). Kuwait. Cited in: el-Asker and Sirajul Haq (eds.), Institutional Framework of Zakat: Dimensions and Implications, Jeddah, IRTI/IDB, pp. 259295.

Ali \& Hatta (2014) cited in Al-Mamun, Abdullah and Haque, Ahasanul (2015). Tax Deduction through Zakah: An Empirical Investigation on Muslim in Malaysia, Vol. 4(2) I July December 2015

Al-Mamun, Abdullah and Haque, Ahasanul (2015). Tax Deduction through Zakah: An Empirical Investigation on Muslim in Malaysia, Vol. 4(2) I July - December 2015

Awad, M. H. (1977). Zakah and our Contemporary Economy

Awad, M. H. (1982). Zakah and Sudan's Economy Resources - Unpublished

Awad, Mohammad Hashim (1985) Adjusting Tax Structure to Accommodate in Zakah Management of Zakah in Modern Muslim Society (Eds.) by Imtiazi, I.A., M.A. Mandan, M.A. Niaz and A.H. Derma, Paper presented to the first Seminar on Management of Zakah in Modern Muslim Society held in Karachi, Pakistan during 02-12 Sha'aban 1405 H (22 April -02 May 1985). Islamic Development Bank Islamic Research and Training Institute

Awad, Mohammad Hashim (1989). "Adjusting Tax Structure to Accommodate Zakah", in: I. A. Imtiazi, et al., (eds.), Management of Zakah in Modern Society, Jeddah, IRTI, IDB, pp. 7796.

Awan, M. Mahmud (1980). Economic Policy for Development - A Treatise on Zakat, in Raquibuzzaman (Ed.). Some Aspects of the Economics of Zakah, pp. 185-207.

Azharuddin, M., (1988). "Role of Zakat in a Modern Economy with Reference to Bangladesh," in: Rafiqul-Islam Molla (et al.) (eds.), Frontiers and Mechanics of Islamic Economics, Sokoto, Nigeria, University of Sokoto, pp. 155-68. 
Azmi, Sabhuddin (2009). Islamic Economics: Public Finance in Early Islamic Thought, Goodword Books, New Delhi, India.

Balogun, S.U. (1999). "Re-appraisal of the Method of Collection and Distribution of Zakah in Nigeria" in: Bashar, M.A.L and Aminu S.M. (eds.), Figh and Economics, Sokoto: Usman Danfodio University, pp. 39-47.

Cizakca, M, (2000), “A History of Philanthropic Foundation: The Islamic World from the Seventh Century to the Present", Istanbul: Bogazici University Press.

Chapra, Umar M. (1979). The Islamic Welfare State and its Role in the Economy, The Islamic Foundation, Leicester, United Kingdom.

Chowdhury, Nuimuddin (1983). Aggregate Demand and Zakah, Thoughts on Economics, vol. 4(9), pp. 1-8.

Darwish, Ahmad Fad and Zain, Mahmud Siddiq (1985). Comments on Metwally in Journal of Research in Islamic Economics, vol. 2(2), pp. 121-130.

Dogarawa, A.B. (2009). Poverty Alleviation through Zakah and Waqf Institutions: A Case for the Muslim Ummah in Ghana. Online at https://mpra.ub.unimuenchen.de /23191/MPRA Paper No. 23191, posted 10. June 2010 13:38 UTC

Duncan, O.D. (1961). A Socioeconomic Index for all Occupations, pp. 109-138 in Occupations and Social Status, edited by Albert J. Reiss, Jr. New York: Free Press.

El-Din, S.I. Tag (1986). Allocative and Stabilizing Functions of Zakat in an Islamic Economy, Paper Presented at the International Seminar on Fiscal Policy and Development Planning in an Islamic State, Islamabad.

Faridi, F.R. (1983). A theory of fiscal policy in an Islamic state, A paper published in "A Fiscal Policy and Resource Allocation in Islam" edited by Ziauddin Ahmed, Munawar Iqbal, M. Fahim Khan Munawar.

Faridi, F. R., (1995). “India”, (a case study of Zakah Management), in: el-Ashker and Sirajul Haq (eds.), Institutional Framework of Zakah: Dimensions and Implications, Jeddah, IRTI, IDB, pp. 231-57.

Fuadah, et al., (2013). cited in Malik, Bilal Ahmad (2016). Philanthropy in Practice: Role of Zakah in the Realization of Justice and Economic Growth, International Journal of Zakah, vol. 1(1) 2016 pp. 64-77.

Hairunnizam Wahid, Radiah Abdul Kader and Ahmad, Sanep (2012). Localization of Zakah Distribution, Religiosity, Quality of Life and Attitude Change (perceptions Zakah recipients in Malaysia), paper presented at the $13^{\text {th }}$ Malaysia Indonesia Conference on Economics, Management and Accounting 2012 pp. 2-3

Hassan, Riaz (2007). Giving and Gaining: Philanthropy and Social Justice in Muslim Societies. Lahore Journal of Policy Studies, Vol. 1, No. 1, pp. 25-35 
Hoque, Khan and Mohammad (2015). Poverty Alleviation by Zakah in a Transitional Economy: A Small Business Entrepreneurial Framework. Journal of Global Entrepreneurship Research, Vol. 5, No. 7

Ibrahim, P. and V. Nirmala (2011). Relevance of Islamic Economic Measures in Achieving Inclusive Growth in Muslim Minority Countries: A Case Study of Kerala, India. 8th International Conference on Islamic Economics and Finance on Sustainable Growth and Inclusive Economic Development from an Islamic Perspective: Linking Research with Policy, Qatar, 19-21 December, 2011.

IMF (2015). cited in Malik, Bilal Ahmad (2016). Philanthropy in Practice: Role of Zakah in the Realization of Justice and Economic Growth, International Journal of Zakah, vol. 1(1) 2016 pp. 64-77.

Imtiazi, I. A., M. A. Mandan, M. A. Niaz, and A. H. Deria, (eds.). (1989). Management of Zakah in Modern Muslim Society. Jeddah: Islamic Development Bank.

Iqbal, Munawar (1985). Economic Activity: An Islamic Perspective Islamabad, Discussion Paper Series No. 1.

Iqbal, Munawar (eds.). (2002). Islamic Institutions and the Elimination of Poverty. Leicester: The Islamic Foundation

Karwai, S.A. (2012). Islamic Economic Development, in Kawai, S.A., A.G, Harbin, and B.T. Jibril (2012). Ed. Islamic Economics: A Book of Readings, Published by the International Institute of Islamic Thought (IIIT), Nigeria Office.

Kahf, M. (1980). "A Contribution to the Theory of Consumer Behaviour in an Islamic Society", in Studies in Islamic Economics by Ahmad, K., Ed. Leicester: The Islamic Foundation.

Kahf, M. (1983). “Taxation policy in Islamic economy" A paper published in "A fiscal policy and resource allocation in Islam" edited by Ziauddin Ahmed, Munawar Iqbal, M. Fahim Khan Munawar.

Kahf, M. (1989). Principles of Socioeconomic Justice in the Contemporary Figh of Zakah, Jeddah: Islamic Research Training Institute, Islamic Development Bank.

Kahf, M. (1997). Potential Effects of Zakah on Government Budget. IIUM Journal of Economics and Management, 85.

Kahf, M. (1999). “The Performance of the Institution of Zakah in Theory and Practice", Paper Presented at the International Conference on Islamic Economics towards the 21st Century, Kuala Lumpur

Kahf, M. (1999). "The Principle of Socio-Economic Justice in the Contemporary Fiqh of Zakah", at: http://monzer.kahf.com/papers/english/socioeconomic\%20justice

Khan, Muhammad Akram (1983). Islamic Economics: Annotated sources in English and Urdu, The Islamic Foundation, Leicester UK. 
Khan, M. Fahim (1984). Macro Consumption Function in an Islamic Framework, Journal of Research in Islamic Economics, vol. 1(2), pp. 1-24.

Khan, Muhammad Akram (1994). An Introduction to Islamic Economics: Islamization of Knowledge Series, 13, Islamabad, the International Institute of Islamic Thought (IIIT) and the Islamic Research Training Institute (IRTI), Jeddah, Saudi Arabia.

Khan, Muhammad Akram (1995), "Legal, Administrative, and Financial Control", in: elAshker and Sirajul Haq (eds.), Institutional Framework of Zakah, Jeddah, IRTI/IDB, pp. 65102.

Khan, M. F. (2007). Integrating Faith-based Institutions (Zakah and Awqaf) in Poverty Reductions Strategies (PRS). Islamic Research and Training Institute (IRTI), 31.

Kuran, T. (2006). Islam and Mammon: The Economics Predicaments of Islamism, Oxfordshire: Princeton University Press.

Malik, Bilal Ahmad (2016). Philanthropy in Practice: Role of Zakah in the Realization of Justice and Economic Growth, International Journal of Zakah, vol. 1(1) 2016 pp. 64-77.

Mannan, M.A. (1983). Zakah, Its Disbursement and Inter-poor Distributional Equity, Thoughts on Economics, vol. 4(8), pp. 2-14.

Mawdudi, Abul A'la (1975). Political Theory of Islam, in Islam, Its Teachings and Massage, (Eds.) Kurshid Ahmad, Islamic Publication Bureau, Lagos, Nigeria, pp. 147-172.

Mawdudi, Abul A'la (1988). May'ashiaat-i-Islam, Islamic Publications, Lahore.

Metwally, M.M. (1983). "Fiscal policy in an Islamic economy", A paper published in "A Fiscal Policy and Resource Allocation in Islam", edited by Ziauddin Ahmed, Munawar Iqbal, M. Fahim Khan Munawar.

Metwally, M.M. (1986). The Effect of Religious Tax on Zakah on Investment in an Islamic Economy, Humanomics, vol.2(2), pp. 43-55.

Mohsin, Magda Ismail A. (2013). Potential of Zakat in Eliminating Reba and Eradicating Poverty in Muslim Countries, European Journal of Business Management, Vol. 12(11).

Norulazidah P.H. Omar Ali, D. H., and Myles, Gareth D. (2010). The Consequences of Zakah for Capital Accumulation. Journal of Public Economic Theory, 12(4), 837-856. doi:10.1111/j.1467-9779.2010.01476.x

Sadeq, M. Abdul Hassan (1990). Economic Development in Islam, Pelanduk Publication, Kuala Lumpur, Malaysia.

Qardawi, Y. (1997). “Zakah Role in curing Social and Economic Malaise (Arabic)”, Economics of Zakah: Book of Reading, Eds. Monzer Kahf, Islamic Research and Training Institute, Jeddah, Saudi Arabia.

Qardawi, Y. (1999). Fiqh az-Zakah (Arabic), Dar al-Taqwa Ltd, London. 
Rabi, Hifzur (2006). Economic Justice in Islam: Monetary Justice and the Way out of Interest (Riba), Published by A.S. Noordeen, Kuala Lumpur, Malaysia.

Raimi, L., Patel, A., Adelopo, I., and Ajewole, T. (2013), “Tackling poverty crisis in the Muslim Majority Nations (MMNs): The Faith-Based Model (FBM) as an alternative policy option". Advanced Journal of Business Management and Entrepreneurship, 1(1), pp. 1-12.

Rahman, M. (2003). Zakah Calculation: Primarily Based on Figh-uz-Zakah by Yusuf-al-Qardawi, Leicester: The Islamic Foundation.

Sadly, (1990). In A Survey of the Institutions of Zakat: Issues, Theories and Administration, Discussion Paper, Islamic Development Bank (IDB) and Islamic Research and Training Institute (IRTI).

Salama, A. A. (1983). "Fiscal Policy of an Islamic state" published in Fiscal Policy and Resource Allocation in Islam Edited by Ziauddin Ahmed, Munawar Iqbal and M. Fahim Khan International Centre for Research in Islamic Economics King Abdulaziz University, Jeddah and Institute of Policy Studies, Islamabad.

Sarif, Shaili and Nor 'Azzah Kamri (2009). A Theoretical Discussion of Zakat for Income Generation and its Fiqh Issues, Shari' ah Journal, Vol. 17 (3), pp. 457-500. http://www.thefreedictionary.com/receivable.

Shirazi and Amin (2006). cited in Malik, Bilal Ahmad (2016). Philanthropy in Practice: Role of Zakah in the Realization of Justice and Economic Growth, International Journal of Zakah, vol. 1(1) 2016 pp. 64-77.

Shehatah, Shawki Ismail (1985). "Limitations on the Use of Zakah Funds in Financing the Socioeconomic Infrastructure of Society"

Shehatah, Shawki Ismail (1989). "Limitations on the use of Zakah Funds in Financing the Socioeconomic Infrastructure of Society", Imtiazi et al (eds.) Management of Zakah in Modern Muslim Society, Islamic Institute of Research and Training, Jeddah, Saudi Arabia

Siddiqi, S. A. (1979). "Zakah", in Public Finance in Islam by Sheik Muhammad Ashraf, Ed., Lahore: Islamic Publications.

Yakoob, A. (2009). Case for Interest-free Financial Institutions in Kerala. Unpublished Ph.D. Dissertation, Kottayam, India: Submitted to M. G. University.

Yusoff, Wan Sulaiman bin Wan (2008). Modern Approach of Zakah as an Economic and Social Instrument for Poverty Alleviation and Stability of Ummah. Jurnal Ekonomi dan Studi Pembangunan, Vol. 9, No. 1, pp.

Ziauddin A., M. Iqbal, M. and F. Khan (1983). Selected papers presented to the first Seminar held in Islamabad, King Abdul Aziz University, Jeddah, and Institute of Policy Studies, Islamabad. 
Zarqa, M.A. (1976). Macroeconomic Estimation of Potential Zakah Proceeds, and their Relationship to economic Development, Paper submitted to the Symposium on Islam and Development (Philadelphia: April 1976);

Zarqa, M.A. (1997). "Role of Zakah in the Economy and in Fiscal Policy (Arabic)”, Economics of Zakah: Book of Reading, Kahf (eds.), Islamic Research and Training Institute, Jeddah, Saudi Arabia. 